\title{
Effect of illumination and emersion period on the exchange of ammonium across the estuarine sediment-water interface
}

\author{
Daniel C. O. Thornton*, Graham J. C. Underwood, David B. Nedwell \\ Department of Biological Sciences, John Tabor Laboratories, University of Essex, Colchester, Essex CO4 3SQ, \\ United Kingdom
}

\begin{abstract}
The metabolic activity of the microphytobenthos may effect inorganic nutrient exchange across the sediment-water interface. Ammonium exchange across the sediment-water interface was investigated in intact sediment cores and microphytobenthos isolated using lens tissue. Ammonium uptake rates of lens tissue extracts in darkness were $11.4 \pm 5 \mu \mathrm{mol}(\mathrm{mg} \mathrm{chl} \mathrm{a})^{-1} \mathrm{~h}^{-1}$ (mean $\pm \mathrm{SE}$ ). Uptake by lens tissue extracts was 2 to 5 times greater in the light than dark; however, uptake under illumination was not correlated with photosynthetically available radiation (PAR) intensity. Emersion under illumination and in the dark affected ammonium exchange after immersion in sediment cores. In darkemersed cores there was net ammonium efflux from the sediment into the overlying water after immersion. An illuminated emersion period reduced the flux of ammonium to the overlying water or affected uptake after immersion. There was a significant positive relationship between the length of the period of emersion under illumination (and therefore photosynthesis) and the subsequent ammonium demand of the sediment after immersion. Porewater profiles revealed low ammonium concentrations in illuminated-emersed cores compared to dark-emersed and dark-immersed cores. Ammonium demand in illuminated-emersed cores was a result of direct and indirect effects by the microphytobenthos. As well as direct ammonium uptake in the light, the production of oxygen probably stimulated oxic bacterial processes such as nitrification $\left(\mathrm{NH}_{4}^{+} \rightarrow \mathrm{NO}_{3}^{-}\right)$in the surface of the sediment. These data show that the effect of the illumination and emersion period should be considered when nutrient budgets are calculated for intertidal, cohesive sediments dominated by microphytobenthos.
\end{abstract}

KEY WORDS: Ammonium - Microphytobenthos - Nutrient exchange · Estuarine - Emersion period Ammonium uptake. Diatom

\section{INTRODUCTION}

Estimates of the degree of attenuation of inorganic nutrient (nitrite, nitrate, ammonium, phosphate and silicate) loads by estuaries are vital to our understanding of the ecology of coastal seas. In order to understand nutrient budgets of estuaries and coastal systems it is important to measure, and incorporate into models, the effects of the microphytobenthos on nutrient exchange across the sediment-water interface. Photosynthesis by the microphytobenthos may effect nutrient exchange either directly through uptake or indirectly through oxygenation of the surface layers of sediment; the cumulative effect of microphytobenthic

·E-mail: dan@essex.ac.uk activity may be sufficient to effect nutrient loading in the estuary and consequently input to the coastal sea.

The effect of the microphytobenthos on nutrient exchange has been largely overlooked, despite the fact that photosynthetic biofilms form a substantial part of the biomass of eulittoral sediments (Admiraal 1984, Wiltshire 1992, Underwood \& Paterson 1993a,b, de Jonge \& Colijn 1994) and contribute significantly to total primary production in shallow areas (Revsbech \& Jørgensen 1983, Brotas \& Catarino 1995). Nutrient fluxes in estuarine systems have usually been measured in darkened cores (Nedwell \& Trimmer 1996, Ogilvie et al. 1997, Trimmer et al. 1998), with few exceptions (Sundbäck et al. 1991), and typically show an efflux of ammonium from the sediment to the overlying water. However, when illuminated, the micro- 


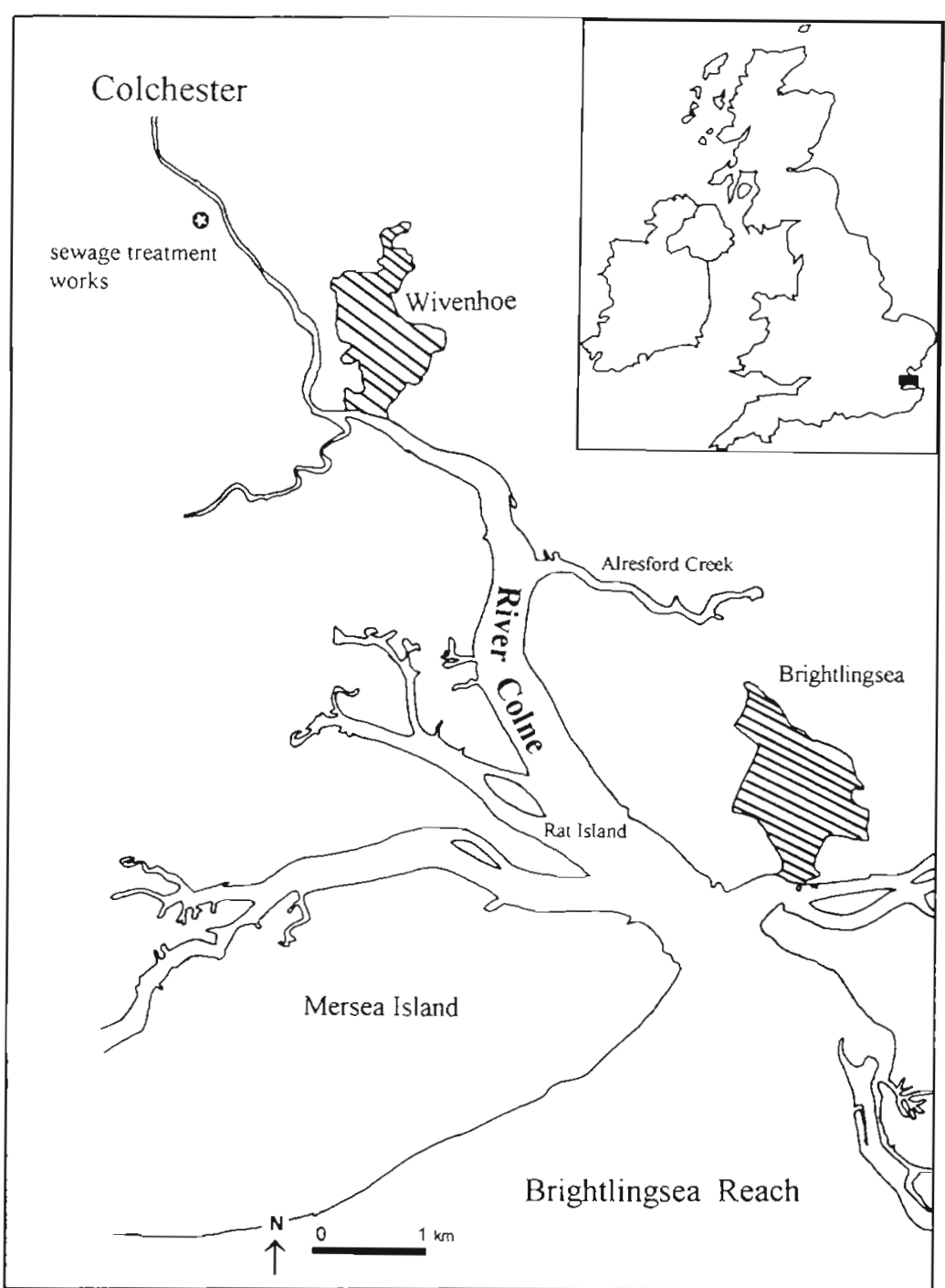

Fig. 1 The Colne estuary system on the east coast of Britain (see inset) showing the position of the sampling site in Alresford Creek $\left(51^{\circ} 50^{\prime} \mathrm{N}, 1^{\circ} 0^{\prime} \mathrm{E}\right.$ ) and sewage treatment works along the estuary limited or non-existent. Oxygen penetration into the sediment may be increased during emersion (Brotas et al. 1990). This may result in a stimulation of the aerobic process of nitrification $\left(\mathrm{NH}_{4}^{+} \rightarrow \mathrm{NO}_{3}{ }^{-}\right)$ and potential inhibition of the facultative anaerobic process of denitrification $\left(\mathrm{NO}_{3}{ }^{-} \rightarrow \mathrm{N}_{2}\right)$. It has been shown that the flooding of intertidal muds results in a rapid release of ammonium (Falcão \& Vale 1995, Cabrita 1997) in Portuguese estuaries over a time-scale of minutes. Such effects will not be accounted for in work which uses permanently flooded cores from intertidal sediments. The effect of light on nutrient exchange needs to be established on intertidal sediments and at subtidal locations where light penetrates the water column and reaches the sediment surface.

This work resulted from observations during annual surveys in the Colne and Great Ouse estuaries (east coast, UK) that the direction of ammonium flux was af fected by illumination and darkness (Thornton et al. unpubl.). The aim of the present work was to test 3 hypotheses: firstly, that net ammonium uptake by sediments is affected by the microphytobenthos under illumination; secondly, that the length of emersion period effects the magnitude of ammonium flux on immersion; and, finally, that there may be a rapid and significant exchange of ammonium during the first few minutes after immersion which is not accounted for during measurements on permanently flooded cores. phytobenthos may have a strong regulatory effect on the efflux of nutrients from the sediment in estuaries (Rysgaard et al, 1995).

Much of the work carried out on nutrient exchange has investigated sublittoral (Sundbäck et al. 1991, Hall et al. 1992, Rysgaard et al. 1995, Conley et al. 1997, Gilbert et al. 1997) and subtidal (Nedwell \& Trimmer 1996, Trimmer et al. 1998) sites. Attempts have been made to account for the effect of emersion period on nutrient exchange (Feuillet-Girard et al. 1997), but in this work the sediment was immersed during the emersion period. During the emersion period the physical state of the mudflat surface changes due to drainage and evaporation (Feuillet-Girard et al. 1997) and nutrient exchange across the sediment surface in the aqueous phase is

\section{MATERIALS AND METHODS}

Site characteristics. Samples were taken in Alresford Creek $\left(51^{\circ} 50^{\prime} \mathrm{N}, 1^{\circ} 0^{\prime} \mathrm{E}\right)$, which is part of the Colne estuary system (Essex, UK). The Colne is a relatively small (approximately $16 \mathrm{~km}$ long; Underwood et al. 1998) eutrophic estuary which runs into the North Sea on the east coast of England (Fig. 1). There is a pronounced gradient of nutrients $\left(\mathrm{NO}_{3}{ }^{-}, \mathrm{NH}_{4}{ }^{+}\right.$and $\mathrm{PO}_{4}{ }^{2-}$ ) contrary to the salinity gradient (Ogilvie et al. 1997). A large sewage treatment works serving Colchester is located at the head of the estuary; concentrations of nitrate and ammonium may exceed $1 \mathrm{mM}$ in this region (Ogilvie et al. 1997). Alresford Creek was chosen as it has been used in previous work; it is rep- 
resentative of the central section of the estuary, halfway along the pronounced nutrient gradient, where there are extensive intertidal mudflats of cohesive muds characterised by silts.

Experimental approach. Experiments were conducted with sediment cores and lens tissue extracts of the microphytobenthos incubated in the laboratory at in situ temperature. On each sampling occasion (Table 1) site water was collected and sediment cores were taken at random from the mid to low shore. On each sampling occasion 5 cores $(80 \mathrm{~mm}$ internal diameter, $20 \mathrm{~cm}$ deep) were taken to characterise the site sediment. The cores were returned to the laboratory within an hour of leaving the site and subsamples of the surface 0 to $5 \mathrm{~mm}$ were taken randomly with minicores (18 mm internal diameter). The site sediment was characterised by measuring porosity (determined from the wet and dry weights of a known volume of sediment), ash-free dry weight (AFDW, $550^{\circ} \mathrm{C}$ for $1 \mathrm{~h}$; Underwood \& Paterson 1993a,b) and chlorophyll a (chl a) (see below). Two sizes of Perspex core tubes were used in the experimental work: small cores (34 $\mathrm{mm}$ internal diameter, $30 \mathrm{~cm}$ long) which were sealed with a rubber bung, and large cores $(80 \mathrm{~mm}$ internal diameter, $65 \mathrm{~cm}$ long) which were sealed with silicone rubber bungs after adjusting the headspace volume above the sediment to $500 \mathrm{ml}$ by pushing the bung up the core tube. All cores were submerged overnight at the in situ temperature (Table 1) under vigorously aerated site water in the dark, which stirred the water above the sediment and simulated nighttime immersion. Experiments were carried out the next day. In all experiments site water was used to immerse the cores. Illuminated incubations were made under $500 \mathrm{~W}$ halogen lamps using a cooled Perspex tray of water as a heat screen. At the end of each experiment the exact headspace volume above the sediment was measured in each core, sediment was taken for chl a analysis and the number of worm burrows were counted to give an indication of infauna activity.

Table 1. Physical and biological characteristics of the site at Alresford Creek $\left(51^{\circ} 50^{\circ} \mathrm{N}, 1^{\circ} 0^{\prime} \mathrm{E}\right)$ during 1997 and 1998 . Values = mean $\pm \mathrm{SE} ; \mathrm{n}=5$ for porosity, ash-tree dry welght (AFDW), chlorophyll a $(\mathrm{chl} a)_{i} \mathrm{n}=3$ for ammonium concentration

\begin{tabular}{|lrccccc|}
\hline $\begin{array}{l}\text { Date } \\
(\mathrm{d} / \mathrm{mo} / \mathrm{yr})\end{array}$ & $\begin{array}{c}\text { Water temp. Porosity } \\
\left({ }^{\circ} \mathrm{C}\right)\end{array}$ & $\begin{array}{c}\text { AFDW } \\
(\%)\end{array}$ & $\begin{array}{c}\mathrm{chl} \mathrm{a} \\
\left(\mathrm{mg} \mathrm{m}^{-2}\right)\end{array}$ & $\begin{array}{c}\mathrm{NH}_{4}{ }^{+} \\
(\mu \mathrm{M})\end{array}$ & Expt \\
\hline $26 / 11 / 97$ & 8 & - & - & $140 \pm 7$ & - & 1 \\
$22 / 04 / 98$ & 15 & $0.67 \pm 0.01$ & $14.7 \pm 0.3$ & $74 \pm 17$ & - & 2 \\
$29 / 04 / 98$ & 15 & $0.66 \pm 0.04$ & $15.0 \pm 0.5$ & $48 \pm 5$ & $15 \pm 2$ & 4 \\
$28 / 05 / 98$ & 15 & $0.77 \pm 0.06$ & $14.2 \pm 0.7$ & $51 \pm 7$ & $33 \pm 3$ & 3 \\
$02 / 06 / 98$ & 17 & $0.74 \pm 0.02$ & $13.8 \pm 2.0$ & $75 \pm 9$ & $183 \pm 1$ & 3 \\
$28 / 07 / 98$ & 18 & - & - & - & - & 5 \\
\hline
\end{tabular}

General methods. Water samples for nutrient analysis were filtered through glass fibre (GF/C) filters and stored at $-20^{\circ} \mathrm{C}$ until analysis. Nutrient concentrations (nitrate + nitrite, ammonium, silicate and phosphate; American Public Health Association 1995, Kirkwood 1996) were measured using a segmented flow autoanalyzer (Skalar SANplus, Skalar Analytical B.V., The Netherlands). Ammonium was also measured manually (Krom 1980).

Chl a was extracted from freeze-dried sediment (surface 0 to $0.5 \mathrm{~cm}$ ) with cold methanol over $24 \mathrm{~h}$ and measured spectrophotometrically, correcting for phaeopigments (Stal et al. 1984). In situ site water temperature was measured using an alcohol thermometer and salinity with a hand-held refractometer. Photosynthetically available radiation (PAR) was measured with a Skye light meter (Skye Instruments Ltd, UK)

Expt 1 -effect of PAR on ammonium uptake by isolated microphytobenthos. Microphytobenthos was extracted from sediment using double layers of lens tissue on exposed mud for 30 min (Eaton \& Moss 1966). Both layers of lens tissue were removed from the mud and the microphytobenthos extracted by agitation in artificial seawater (Tropic Marin ${ }^{\text {TM }}$ sea salts) at $30 \%$ (equivalent to the high tide salinity). Extracted microphytobenthos was stored in aerated flasks overnight at in situ temperature (Table 1). The air was humidified by passing through Milli-Q water (Millipore, Molsheim, France) before the flask. There were negligible traces of ammonium and nitrate in the Tropic Marin ${ }^{\mathrm{TM}}$ sea salts.

Incubations (15 min) were made in a flooded polished steel tray in a water bath at in situ temperature under 2 lamps during the emersion period. Aliquots of $25 \mathrm{ml}$ were placed in $30 \mathrm{ml}$ universal bottles (Bibby Sterilin, Stone, UK) and spiked with $0.25 \mathrm{ml} \mathrm{NH}_{4} \mathrm{Cl}$ made up in artificial seawater (30\%, Tropic Marin ${ }^{\mathrm{TM}}$ ) to a final concentration of $20 \mu \mathrm{M}$. A PAR gradient (14, $26,33,41,48$ and $100 \%$ of incident PAR) was achieved by wrapping the universal bottles in layers of muslin, which acted as a neutral density filter. Dark bottles were wrapped with aluminium foil. There were 3 replicates at each level of PAR. Two experimental runs were carried out, with $100 \%$ PAR of 1000 and $500 \mu \mathrm{mol} \mathrm{m} \mathrm{m}^{-2} \mathrm{~s}^{-1}$ respectively. Uptake rates were calculated from the loss of ammonium from the medium and were normalised to chl a extracted from GF/C filters.

Expt 2-eifect of emersion and light on sediment $\mathrm{O}_{2}$ uptake and ammonium exchange. Nine large sediment cores were taken. The following day, 6 of the cores were drained of site 
water during the in situ emersion period. Three of the emersed cores were incubated under halogen lamps $\left(120 \mu \mathrm{mol} \mathrm{m}^{-2} \mathrm{~s}^{-1}\right)$ and 3 cores were placed emersed in the dark. The remaining cores were left flooded under aerated site water in the dark. The treatments will be referred to as light, dark and control hereafter.

After $6.5 \mathrm{~h}$, the emersed cores were flooded by gently immersing the cores in site water using a large syringe. All cores were capped, ensuring that no air bubbles were trapped in the headspace, and stirred with an induction motor driving a magnetic follower (Rank Brothers Ltd, Cambridge, UK). Oxygen uptake was measured over $90 \mathrm{~min}$ in the dark using oxygen electrodes (model 1302, Strathkelvin Ltd, Glasgow, UK) fitted through the cap of each core. This measurement time was that required to produce a measurable linear oxygen uptake rate, while ensuring that the oxygen saturation within the headspace did not fall below $80 \%$. The electrodes were interfaced to a computer via a 10-channel oxygen meter (Essex Electronics, Colchester, UK). The data analysis software (Notelog ${ }^{\circledR}$, Garrat Consultants, Colchester, UK) allowed continuous logging of the oxygen concentrations in all the cores simultaneously (see Nedwell \& Trimmer 1996). The electrodes were calibrated using Winkler titration (Strickland \& Parsons 1972) to determine the oxygen concentration of $100 \%$ saturated water. Water samples were taken for ammonium analysis at the start and finish of the dark-immersed period.

Expt 3-effect of light and emersion period on ammonium exchange. Small cores were collected and experiments were carried out during the $2 \mathrm{~d}$ after collection of the cores. The cores were treated as shown in Table 2 during the in situ low tide period, with triplicate cores for each treatment. Three experimental runs were carried out with 3 different emersion periods $(2,4$ or $6 \mathrm{~h}$ ). After emersion the cores were flooded with a syringe $(20 \mathrm{ml})$ and incubated under the conditions listed in Table 2. The water column above the sediment was mixed by passing a humidified air stream.

Table 2. Treatments used to investigate the effect of emersion time $(2,4$ and $6 \mathrm{~h})$ and illumination on ammonium exchange across the sediment-water interface. Emersion period corresponded to the period of low tide in which cores were taken the previous day

\begin{tabular}{|c|c|c|c|}
\hline Treatment & \multicolumn{2}{|c|}{$\begin{array}{l}\text { Emersion period } \\
\qquad(2,4 \text { or } 6 \mathrm{~h})\end{array}$} & $\begin{array}{l}\text { Immersion period } \\
\text { (all immersed for } 4 \mathrm{~h} \text { ) }\end{array}$ \\
\hline Control & Immersed & Dark & Dark \\
\hline DD & Emersed & Dark & Dark \\
\hline DL & Emersed & Dark & Light \\
\hline LL & Emersed & Light & Light \\
\hline LD & Emersed & Light & Dark \\
\hline
\end{tabular}

through a syringe needle (19 gauge) suspended $1 \mathrm{~cm}$ above the sediment surface. Samples for ammonium analysis were taken at time zero $\left(t_{0}\right)$, after $2 \mathrm{~h}\left(t_{2}\right)$ and $4 \mathrm{~h}\left(t_{4}\right)$ of immersion. Fluxes were calculated by the subtraction of concentrations at $t_{0}$ from those at $t_{2}$ and from those at $t_{4}$, accounting for the change in headspace volume caused by the removal of the samples.

To examine the effect of emersion period on porewater concentrations in the surface of the sediment, an extra 9 cores were incubated. Three replicates were incubated emersed in the light, emersed in the dark and immersed in the dark. These cores were sacrificed after the emersion period and porewater was separated from the surface $1 \mathrm{~cm}$ of sediment by centrifugation $(3620 \times g$ for $10 \mathrm{~min})$, the porewater was filtered through GF/C filters and stored frozen for ammonium analysis.

Expt 4-short-term ammonium exchange after immersion. Nine large cores were treated as in Expt 2; 3 were emersed under light $\left(120 \mu \mathrm{mol} \mathrm{m} \mathrm{m}^{-2} \mathrm{~s}^{-1}\right), 3$ in the dark and 3 controls were left fully submerged. After an emersion period of $6.5 \mathrm{~h}$, emersed cores were flooded with a syrnge $(20 \mathrm{ml})$. At least two-thirds of water above the controls was changed to ensure that the differences between the treatments were due to immersion rather than water movement above the sediment. After immersion, all treatments were incubated in the dark; water samples for ammonium analysis were taken after $0,15,30,60,120,360$ and $1260 \mathrm{~min}$. The water column above the sediment was mixed by passing a humidified air stream through $5 \mathrm{~mm}$ bore silicone rubber ( $5 \mathrm{~mm}$ i.d.) tubing suspended $2 \mathrm{~cm}$ above the sediment surface. Nutrient fluxes were calculated by subtracting the ammonium concentration at time zero from the ammonium concentration taken at the end of each time period.

Expt 5-effect of light and emersion on porewater ammonium concentrations. Twelve sediment cores ( $80 \mathrm{~mm}$ i.d., $20 \mathrm{~cm}$ long) were collected at low tide, and overlying water was collected the following high tide (Table 1). The cores were submerged in site water and left overnight in aerated water outside under ambient conditions. Eight cores were drained coinciding with the in situ emersion period, and incubated outside at ambient temperature. Four of these drained cores had light excluded with aluminium foil (dark treatment), the other 4 cores were incubated under ambient PAR (light treatment). PAR fluctuated throughout the $5 \mathrm{~h}$ incubation due to cloud cover from 250 to $1500 \mu \mathrm{mol}$ $\mathrm{m}^{-2} \mathrm{~s}^{-1}$. The remaining cores were incubated under site water in the dark at ambient temperature (controls). After $5 \mathrm{~h}, 1$ core from each treatment was sacrificed for chl a (3 replicates from each core) and the remaining cores were sectioned $(0-0.5,0.5-1.0,1.0-1.5,1.5-2.0$ and $2.0-3.0 \mathrm{~cm}$ ) and the porewater was extracted by 


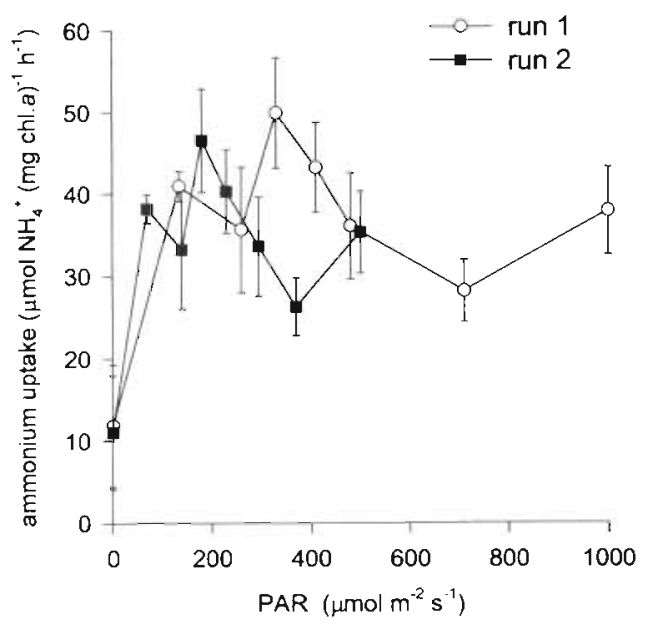

Fig. 2. Ammonium uptake by microphytobenthos extracted from lens tissue over a range of PAR (photosynthetically available radiation) intensities (Expt 1). Values are means $\pm \mathrm{SE}$ $(\mathrm{n}=3)$

centrifugation. The extract was filtered through GF/C filters and stored frozen for ammonium analysis.

Data analysis. Multiple comparisons were made by analysis of variance (ANOVA) followed by post hoc Tukey tests (SYSTAT Products 1997).

\section{RESULTS}

Site characteristics on all sampling occasions are shown in Table 1.

\section{Expt 1 -effect of PAR on ammonium uptake by isolated microphytobenthos}

Isolated microphytobenthos exhibited significantly higher $\left(F_{14,33}=3.952, \mathrm{p}<0.001\right)$ rates of ammonium uptake when illuminated, compared to rates in darkness (Fig. 2). However, there was no significant relationship between PAR intensity and rate of uptake. The data indicate that ammonium uptake was possibly saturated at the lowest PAR intensity of $70 \mu \mathrm{mol}$ $\mathrm{m}^{-2} \mathrm{~s}^{-1}$.

\section{Expt 2-effect of emersion and light on sediment $\mathrm{O}_{2}$ uptake and ammonium exchange}

In either the light or dark, emersion had no significant effect on the subsequent benthic $\mathrm{O}_{2}$ uptake rate once cores were immersed (Fig. 3a). However, treatment during the emersion period did significantly $\left(F_{2,6}\right.$ $=6.132, p<0.05$ ) effect ammonium exchange on subsequent dark immersion compared to the controls (Fig. 3b,c). Ammonium fluxes were greater in the emersed treatments compared to the controls. There was a lower flux of ammonium to the overlying water in the light-emersed compared to the dark-emersed treatment. This pattern was not due to an uneven distribution of microphytobenthos on the surface of the cores as the pattern was maintained when the flux rates were normalised to sediment chl a (Fig. 3c). Worm burrows were recorded in most of the cores $(5.8$ \pm 3.7 ; mean $\pm \mathrm{SE}$ ); however, there was no correlation between the magnitude of ammonium flux and the number of worm burrows in the cores.

\section{Expt 3-effect of light and emersion period on ammonium exchange}

The effect of treatment and emersion period on ammonium exchange across the sediment-water interface is shown in Fig. 4. In those treatments (Table 2) which were placed in the dark throughout the experi-
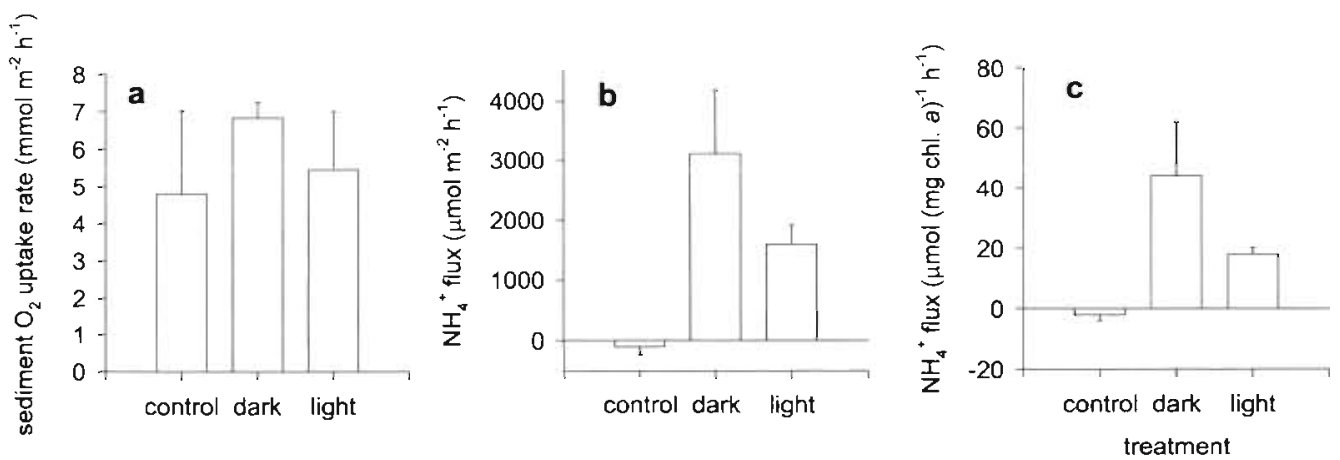

Fig. 3. Fluxes across the sediment-water interface in dark-immersed cores after a $6.5 \mathrm{~h}$ emersion period (Expt 2). The treatments during the emersion period were dark-immersed (control), dark-emersed (dark) and light-emersed (light). Negative values (b,c) indicate uptake and positive values indicate flux to the overlying water column. Values are means $\pm S E(n=3)$. (a) Oxygen flux, (b) ammonium flux, and (c) ammonium flux normalised to sediment chl a 

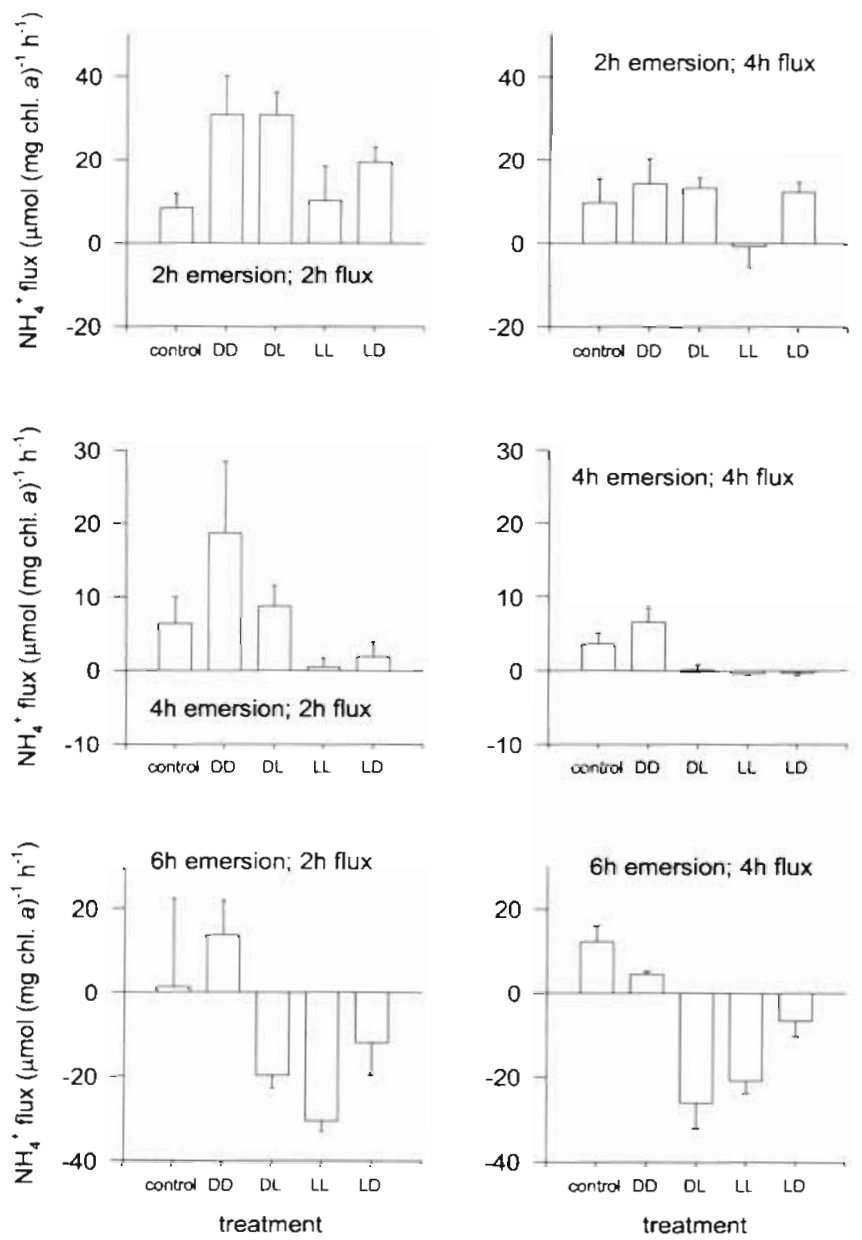

Fig. 4. The relationship between ammonium flux (measured after 2 and $4 \mathrm{~h}$ ) across the sediment-water interface and length of the previous emersion period (Expt 3). Fluxes have been normalised to chl a. Negative values indicate uptake and positive values indicate flux to the overlying water column. Fluxes were measured after 2 and $4 \mathrm{~h}$ of immersion. Treatments were: dark-emersed $\rightarrow$ dark-emersed (DD), darkemersed $\rightarrow$ light-immersed (DL), light-emersed $\rightarrow$ lightimmersed (LL) and light-emersed $\rightarrow$ dark-immersed (LD). See Table 2

ments (control and DD) there was a net fiux oí ammonium from the sediment into the overlying water. In the treatment in which the cores were placed under illumination throughout the experiments (LL) there was a net uptake of ammonium (Fig. 4) from the overlying water or a significant reduction in flux to the overlying water compared to the dark treatments (control and DD). Treatments which were exposed to illumination and darkness (LD and DL) showed an intermediate reaction to illumination; these treatments exhibited a lower ammonium flux to the overlying water or net ammonium uptake compared to DD. Therefore, light had the effect of reducing the flux of ammonium to the overlying water and sometimes resulted in a net ammonium uptake upon immersion.

There were significant effects of treatment (DD, DL, LL \& LD), emersion period $(2,4$ or $6 \mathrm{~h}$ ) and flux time (integrated over 2 or $4 \mathrm{~h}$ ) on the exchange of ammonium across the sediment-water interface. There were significant $(p<0.05)$ interactions between treatment and emersion period, and emersion period and flux time, affecting ammonium exchange. However, there was no significant interaction between treatment and flux time or all 3 factors in affecting ammonium exchange. The analysis ( 3 -way ANOVA, $p<0.05$ ) was carried out on the emersed treatments, the 'control' (permanently immersed) data was removed as the variation in emersion time was irrelevant to this treatment.

ANOVA indicated that treatment and flux time effected ammonium exchange. Normalising the flux data to the controls (Fig. 5) allowed direct comparison of the effect of emersion period on ammonium exchange in different treatments. There were significant ( $p<0.01$ ) negative linear relationships between the length of emersion period and ammonium exchange, except in the DD treatment (Table 2). With longer emersion periods, there was a greater ammonium demand by the sediment on immersion; this led to net uptake of ammonium by the sediment after $6 \mathrm{~h}$ emersion periods (Fig. 5).

\section{Expt 4-short-term ammonium exchange after immersion}

There was a significant difference between treatments and a significant interaction between treatment and time in affecting ammonium flux (2-way ANOVA, $p<0.05$ ) (Fig. 6a). Normalising the flux rates to sediment chl a maintained the patterns observed in the data (Fig. 6b). Cores which were emersed in the light had a lower flux of ammonium to the overlying water than the dark treatment. There was net ammonium uptake by the control treatment; this result was unexpected and counter to previous data (Figs. 2 to 5) and the dark data from this experiment (Fig. 6).

\section{Expt 5-effect of light and emersion on porewater ammonium}

There were significant differences (2-way ANOVA, $p<0.05)$ in porewater ammonium concentrations (Fig. 7) with depth and treatment, and there was an interaction between the 2 factors. The profiles of the dark treatment cores were similar to the controls compared to the light treatment. In all treatments there 

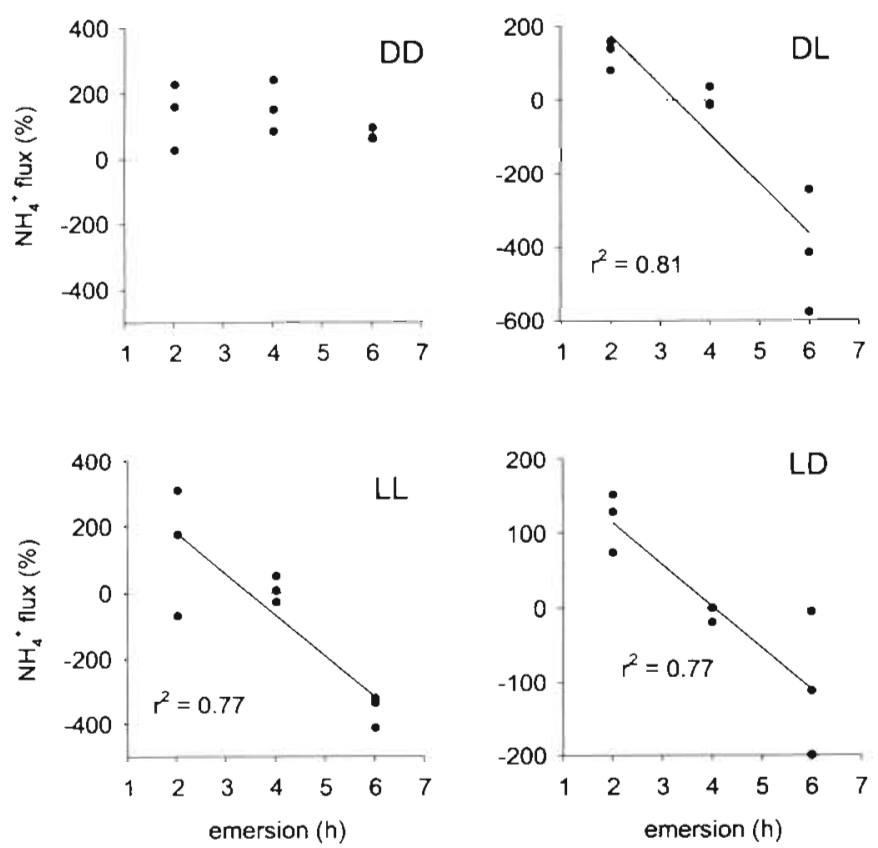

Fig. 5. The relationship between ammonium flux and length of the previous emersion period (Expt 3). Fluxes have been normalised against the control (immersion, immersion) and are expressed as a percentage of the control. Negative values indicate uptake and positive values indicate flux to the overlying water column over a $4 \mathrm{~h}$ immersion period. Treatments were: dark-emersed $\rightarrow$ dark-emersed (DD), dark-emersed $\rightarrow$ light-immersed (DL), light-emersed $\rightarrow$ light-immersed (LL) and light-emersed $\rightarrow$ dark-immersed (LD). See Table 2

was an increase in ammonium concentration with depth. When the porewater profiles were integrated from 0 to $3 \mathrm{~cm}$ depth, the mean ( $\pm \mathrm{SE}$ ) ammonium concentrations were $601 \pm 158$ (control), $452 \pm 93$ (dark) and $199 \pm 15 \mu \mathrm{M}$ (light).

These data were consistent with results from Expt 3 ; after a $6 \mathrm{~h}$ emersion period there was a significant difference $(p<0.01$, Student's $t$-test) in porewater ammonium concentrations between light- and dark-emersed cores. After illumination there was half the free ammonium concentration $(179 \pm 10 \mu \mathrm{M})$ (mean $\pm \mathrm{SE}$ ) in the surface 0 to $1 \mathrm{~cm}$ compared to the dark $(367 \pm 18 \mu \mathrm{M})$.

\section{DISCUSSION}

The results of these experiments demonstrate that photosynthetic activity during illuminated emersion periods effects ammonium flux across the sedimentwater interface on subsequent immersion. Emersion of sediment cores under illumination either reduced the flux of ammonium into the overlying water on immersion compared to dark emersion or induced net ammonium uptake from the overlying water. Associated with
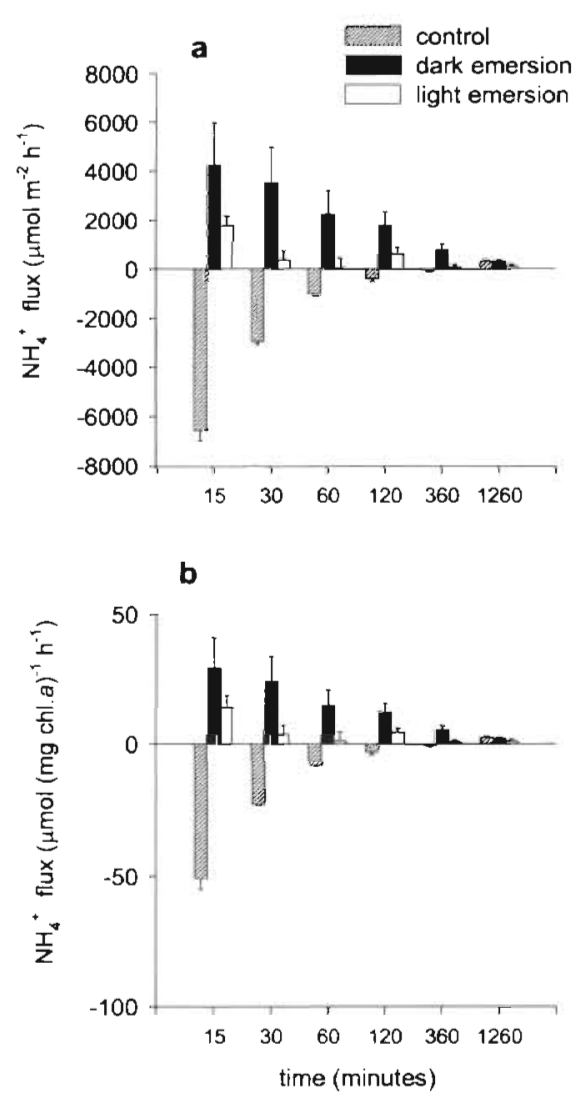

Fig. 6. Changes in ammonium flux across the sediment-water interface with increasing time after emersion (Expt 4). Negative values indicate uptake and positive values indicate flux to the overlying water column. Bars are means + SE $(n=3)$. (a) Amonium flux, and (b) ammonium flux normalised to chl a

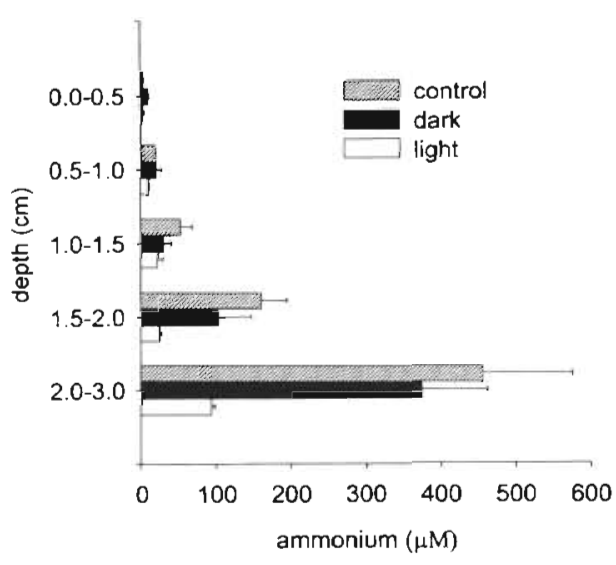

Fig. 7. Porewater profiles of ammonium with depth in sediment cores (Expt 5). Treatments during the $5 \mathrm{~h}$ emersion period were immersed in the dark (control), emersed in the dark (dark), and emersed in the light (light). Bars are means + $\mathrm{SE}(\mathrm{n}=3)$ 
a greater ammonium demand by the sediment after periods of illuminated emersion was a run-down of the porewater ammonium in the sediment surface $(0$ to $3 \mathrm{~cm}$.

The lens tissue method isolated representative microphytobenthos from sediment dominated by epipelic diatoms (Underwood et al. 1998, Smith 1999) and therefore the observed ammonium uptake rates in the dark and under illumination were due to direct uptake by the microphytobenthos. Rates of uptake in the dark were approximately $10 \mu \mathrm{mol}(\mathrm{mg} \mathrm{chl} \mathrm{a})^{-1} \mathrm{~h}^{-1}$ compared to rates of 25 to $50 \mu \mathrm{mol}(\mathrm{mg} \mathrm{chl} \mathrm{a})^{-1} \mathrm{~h}^{-1}$ under illumination. These rates were similar to nitrogen uptake rates by estuarine phytoplankton $(2$ to $70 \mu \mathrm{mol}$ [mg chl a $]^{-1} \mathrm{~h}^{-1}$ ), where ammonium contributed $82 \%$ of the annual nitrogen demand (Pennock 1987). Rates of ammonium uptake by the microphytobenthos under illumination could account for the observed effect of light emersion on ammonium exchange across the sediment-water interface. Cores emersed under illumination in Expt 2 (Fig. 3c) exhibited a flux of approximately $20 \mu \mathrm{mol}(\mathrm{mg} \mathrm{chl} \mathrm{a})^{-1} \mathrm{~h}^{-1}$ less ammonium to the overlying water on immersion compared to cores which were emersed in the dark. Similar effects were seen in Expt 3 ; in all cases the difference in ammonium flux between illuminated and dark-incubated sediments could be accounted for by direct uptake by the microphytobenthos in the light, assuming the rates of uptake by the microphytobenthos were similar to those observed in Expt 1. The mean difference in ammonium flux between the DD and LL treatments (Expt 3) was 3 to $30 \mu \mathrm{mol}(\mathrm{mg}$ chl a) $)^{-1} \mathrm{~h}^{-1}$ (Fig. 4).

Bioturbating infauna are known to effect nutrient exchange across the sediment-water interface (Clavero et al. 1991, Marinelli 1992, Rysgaard et al. 1995). Nereis diversicolor was present in the sediment from which the cores were sampled. However, the number of worm burrows did not correlate with the magnitude of nutrient fluxes. Cores were taken from a small area of sediment to minimise differences in infaunal density between them.

Expt 5 showed that there was run-down of porewater ammonium in the top $3 \mathrm{~cm}$ of illuminated sediment compared to the dark, and an increase in ammonium concentration with depth. Increasing ammonium concentration with depth is well established in estuarine sediments (Feuillet-Girard et al. 1997, Trimmer et al. 1998). Sundbäck et al. (1991) found that porewater ammonium was lower in the surface layers of sediment cores $(0$ to $1.5 \mathrm{~cm}$ ) exposed to a diurnal light-dark regime compared to dark-incubated cores, and there was a significant difference in the magnitude of ammonium flux and sometimes the direction of flux in cores incubated on light-dark cycles.
In the emersed cores there was a run down of ammonium to a depth of at least $3 \mathrm{~cm}$, a depth much greater than the photic zone in estuarine sediments. A $1 \%$ light transmission occurs at $1.1 \mathrm{~mm}$ in estuarine sand and at $0.14 \mathrm{~mm}$ in estuarine mud (Colijn 1982). Photosynthetic oxygen production may have stimulated nitrification $\left(\mathrm{NH}_{4}{ }^{+} \rightarrow \mathrm{NO}_{3}{ }^{-}\right)$by aerobic bacteria in the oxic zone of the sediment (Rysgaard et al. 1994, 1995 Risgaard-Petersen et al. 1994) and caused a run-down of ammonium to a depth greater than the photic zone. However, although photosynthesis may have increased oxygen penetration (Risgaard-Petersen et al. 1994), the sediment would not have been oxic to a depth of $3 \mathrm{~cm}$. Emersion induces greater oxygen penetration, compared to immersion, in sandy sediments (Brotas et al. 1990). However, oxygen penetration during emersion is dependent on sediment type. Brotas et al. (1990) found no difference in oxygen penetration between organically rich muds during emersion and immersion, indicating that emersion would not have affected oxygen penetration in the similar sediments of Alresford Creek. Uptake by the microphytobenthos and stimulated nitrification would have contributed to the run-down of ammonium in the sediment to the observed depth of $3 \mathrm{~cm}$. It is unlikely that diffusion into the oxic zone could account for the observed run-down to $3 \mathrm{~cm}$ depth in this work and $1.5 \mathrm{~cm}$ observed by Sundbäck et al. (1991). These depths, in both our work and that of Sundbäck et al. (1991), represent the maximum depth sampled and not the maximum depth of ammonium run-down in illuminated sediments. The actual ammonium run-down within the sediment may have been to an even greater depth.

Length of emersion period effected ammonium exchange across the sediment-water interface. Long emersion periods under illumination reversed the direction of ammonium flux, resulting in ammonium uptake from the overlying water on immersion. There was a reduction in ammonium efflux from the sediment to the overlying water with shorter illuminated emersion periods. In previous work using estuarine sediments a net flux of ammonium into the overlying water was observed (Nedwell \& Trimmer 1996, Ogilvie et al. 1997, Trimmer et al. 1998); however, these data were based on cores which were constantly immersed in the dark, with no account for either the emersion period or illumination. In Portuguese sediments there was a rapid flux of ammonium to the overlying water (Falcão \& Vale 1995, Cabrita 1997) as the sediment was flooded. The suspended loads of estuaries on the east coast of southern England are very high and it is unlikely that the surface of the sediment will receive any light after flooding with more than a few $\mathrm{cm}$ depth of water (mean vertical light extinction coefficient was $2.63 \mathrm{~m}^{-1}$ near Alresford Creek between September 


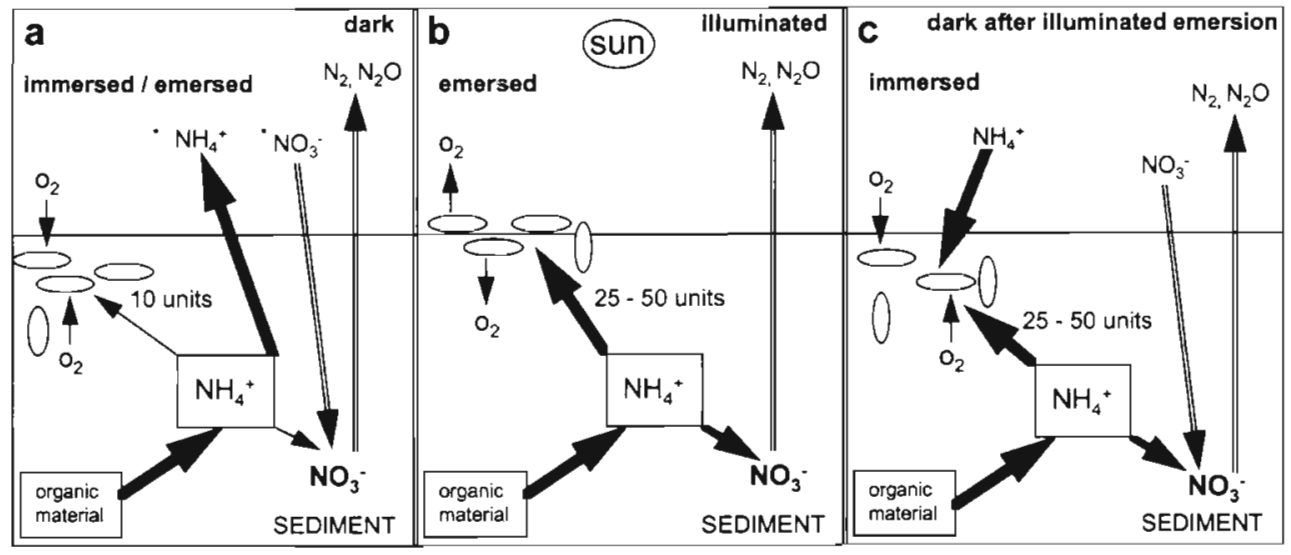

Fig. 8. A summary of the effects of the microphytobenthos on nitrogen fluxes across the sediment-water interface in the light and dark. Arrow width serves as a hypothetical indicator of flux magnitude. The 'units' are ammonium uptake rates by the microphytobenthos in $\mu \mathrm{mol}(\mathrm{mg} \mathrm{chl} \mathrm{a})^{-1} \mathrm{~h}^{-1}$ (a) Dark processes. These processes may occur during both immersion and dark emersion periods. Ammonium and nitrate exchange $(\cdot)$ will only occur underwater during the immersion period. Regeneration of porewater ammonium occurs during these periods and there is a net flux to the overlying water during immersion, (b) Light processes. These processes will only occur during daylight emersion periods. There is an increased ammonium demand within the sediment by the microphytobenthos, and nitrifying bacteria stimulated through photosynthetic oxygen production. Ammonium demand leads to a run-down of ammonium in the surface of the sediment. (c) Dark processes after an illuminated emersion period. The previous illuminated emersion period continues to effect sediment processes into the following dark immersion period, leading to a continued ammonium demand by the sediment which may last several hours. There may be net ammonium uptake by the sediment or a reduced flux of ammonium to the overlying water

1994 and September 1995, Koçum 1998). Therefore, the likely situation in situ is DD (emersion at night followed by immersion during the day or night) or LD (emersion during the day followed by immersion during the day or night).

In the environment the microphytobenthos are exposed to inorganic nitrogen in the form of nitrate as well as ammonium. It is established that ammonium is more readily assimilated by marine phytoplankton than nitrate (Dortch 1990). In estuarine benthic diatoms there is an assimilation preference for ammonium over nitrate (Admiraal et al. 1987, Feuillet-Girard et al. 1997). Our data showed that illumination affects the exchange of the principal inorganic nitrogen source of the microphytobenthos. Fig. 8 summarises the relationship between the microphytobenthos and nitrogen fluxes across the sediment-water interface both in the dark and under illumination. In situ ammonium fluxes will be a function of nutrient concentrations, biological activity and biomass, PAR received, and emersion time. It is clear that current nutrient budgets of macrotidal estuaries do not account for illuminated emersion periods. Previous attempts to account for the effect of illumination during the emersion period have used sediment which was immersed throughout the tidal cycle (Feuillet-Girard et al. 1997). In other work on macrotidal estuaries no account has been taken for the effect of either illumination or emersion as the nutrient exchange data were based on cores which were constantly immersed in the dark (Nedwell \& Trimmer
1996, Ogilvie et al. 1997, Trimmer et al. 1998). The present study indicates that, where intertidal sediments are dominated by microphytobenthic biofilms, the combined effects of emersion period and illumination will result in reduced fluxes of ammonium to the overlying water column on immersion. On the macro-scale this will lead to a reduced export of dissolved inorganic nitrogen (DIN) to the coastal sea from estuaries with extensive microphytobenthic biofilms. DIN will be assimilated by the microphytobenthos and transformed into biomass, this biomass will eventually be transported from the mudflats as particulate organic nitrogen or mineralised back to ammonium.

Acknowledgements. Funded under contract (EPG 1/9/76) to the UK Department of the Environment. Transport and the Regions as a contribution to its co-ordinated programme of marine research for the North-East Atlantic. This research is funded in part by the EU research programme 'Preserving the Ecosystem' under NICE Project contract MAS3-CT96-0048. It is contribution ELOISE No. 085.

\section{LITERATURE CITED}

Admiraal W (1984) The ecology of estuarine sediment-inhabiting diatoms. Prog Phycol Res 3:269-322

Admiraal W, Riaux-Gobin C, Laane RWPM (1987) Interactions of ammonium, nitrate and $\mathrm{D}$ - and L-amino acids in the nitrogen assimilation of two species of estuarine benthic diatoms. Mar Ecol Prog Ser 40:267-273

American Public Health Association (1995) Standard methods for the examination of water and waste water. American Public Health Association, Washington, DC 
Brotas V, Caterino F (1995) Microphytobenthos primary production of Tagus estuary intertidal flats (Portugal). Neth J Aquat Ecol 29(3-4):333-339

Brotas V, Amorim-Ferreira A, Vale C, Catarino F (1990) Oxy gen profiles in intertidal sediments of Ria Formosa (S. Portugal\}. Hydrobiologia 207:123-129

Cabrita MTCMV (1997) Inorganic nitrogen dynamics in the Tagus Estaury (Portugal). Spatial and temporal variation in input and uptake of nitrate and ammonium. PhD thesis, Universidade de Lisboa

Clavero V, Niell FX, Fernandez JA (1991) Effects of Nereis diversicolor O.F. Muller abundance on the dissolved phosphate exchange between sediment and overlying water in Palmones River estuary (Southern Spain). Estuar Coast Shelf Sci 33:193-202

Colijn F (1982) Light adsorption in the waters of the Ems-Dollard estuary and its consequences for the growth of phytoplankton and microphytobenthos. Neth J Sea Res 15 $196-21.6$

Conley DJ, Stockenberg A, Carman R, Johnstone RW, Rahm L. Wulff $F$ (1997) Sediment-water nutrient fluxes in the Gulf of Finland, Baltic Sea. Estuar Coast Shelf Sci 45: $591-598$

de Jonge VN, Colijn F (1994) Dynamics of microphytobenthos biomass in the Ems estuary. Mar Ecol Prog Ser 104: $185-196$

Dortch Q (1990) The interaction between ammonium and nitrate uptake in phytoplankton. Mar Ecol Prog Ser 61 183-201

Eaton JW, Moss B (1966) The estimation of numbers and pigment content in epipelic algal populations. Limnol Oceanogr 11:584-595

Falcão M, Vale C (1995) Tidal flushing of ammonium from intertidal sediments of Ria Formosa, Portugal. Neth J Aquat Ecol 29:239-244

Feuillet-Girard M, Gouleau D, Blanchard G, Jossard L (1997) Nutrient fluxes on an intertidal mudflat in MarennesOléron Bay, and influence of the emersion period. Aquat Living Resour 10:49-58

Gilbert F, Souchu P, Bianchi M, Bonin P (1997) Influence of shellfish farming activities on nitrification, nitrate reduction to ammonium and denitrification at the water-sediment interface of the Thau lagoon, France. Mar Ecol Prog Ser 151:143-153

Hall PO, Holby O, Kollberg S, Samuelsson MO (1992) Chemical fluxes and mass balances in a marine fish cage farm. IV. Nitrogen. Mar Ecol Prog Ser 89:81-91

Kirkwood DS (1996) Nutrients: practical notes on their determination in seawater Techniques in marine environmental science no. 17. ICES, Copenhagen

Koçum E (1998) Phytoplankton primary production along a eutrophic. turbid estuarine gradient (Colne estuary, UK). PhD thesis, University of Essex

Krom MJD (1980) Spectrophotometric determination of ammonia: a study of a modified Berthelot reaction using salicylate and dichloroisocyanurate. The Analyst 105: $305-317$

Marinelli RL (1992) Effects of polychaetes on silicate dynamics and fluxes in sediments: importance of species, animal activity and polychaete effects on benthic diatoms. J Mar Res 50:745-779

Editorial responsibility: Otto Kinne (Editor),

Oldendorf/Luhe, Germany
Nedwell DB, Trimmer M (1996) Nitrogen fluxes through the upper estuary of the Great Ouse, England: the role of the bottom sediments. Mar Ecol Prog Ser 142:273-286

Ogilvie B, Nedwell DB, Harrison RM, Robinson A, Sage A (1997) High nitrate, muddy estuaries as nitrogen sinks: the nitrogen budget of the River Colne estuary (United Kingdom). Mar Ecol Prog Ser 150:217-228

Pennock JR (1987) Temporal and spatial variability in phytoplankton ammonium and nitrate uptake in the Delaware estuary. Estuar Coast Shelf Sci 24:841-857

Revsbech NP, Jorgensen BB (1983) Photosynthesis of benthic microflora measured with high spatial resolution by the oxygen microprofile method: capabilities and limitations of the method. Limnol Oceanogr 28:749-756

Risgaard-Petersen N, Rysgaard S, Nielsen NP, Revsbech NP (1994) Diurnal variation of denitrification and nitrification in sediments colonized by benthic microphytes. Limnol Oceanogr 39(3):573-579

Rysgaard $S$, Risgaard-Petersen N, Sloth NP, Jensen $K$, Nielsen LP (1994) Oxygen regulation of nitrification and denitrification in sediments. Limnol Oceanogr 39(7): $1643-1652$

Rysgaard S, Christensen PB, Nielsen LP (1995) Seasonal variation in nitrification and denitrification in estuarine sediment colonized by benthic microalgae and bioturbating infauna. Mar Ecol Prog Ser 126:111-121

Smith DJ (1999) Exopolymer production of epipelic diatoms. PhD thesis, University of Essex

Stal LI, van Gemerden H, Krumbein WE (1984) The simultaneous assay of chlorophyll and bacteriochlorophyll in natural microbial communities. J Microbiol Methods 2: 295-306

Sundbäck K, Enoksson V, Granéli W, Pettersson K (1991) Influence of sublittoral microphytobenthos on the oxygen and nutrient flux between. sediment and water: a laboratory continuous-flow study. Mar Ecol Prog Ser 74:263-279

Strickland JDH, Parsons TR (1972) A practical handbook of seawater analysis. Fisheries Research Board of Canada, Ottawa

SYSTAT Products (1997) SYSTAT Version 7.0. SPSS Inc Chicago

Trimmer M, Nedwell DB, Sivyer DB, Malcolm SJ (1998) Nitrogen fluxes through the lower estuary of the river Great Ouse, England: the role of the bottom sediments. Mar Ecol Prog Ser 163:109-124

Underwood GJC, Paterson DM. (1993a) Recovery of intertidal benthic diatoms after biocide treatment and associated sediment dynamics. J Mar Biol Assoc UK 73:25-45

Underwood GJC, Paterson DM (1993b) Seasonal changes in diatom biomass, sediment stability and biogenic stabilization in the Severn Estuary. J Mar Biol Assoc UK 73: $871-887$

Underwood GJC, Phillips J, Saunders K (1998) Distribution of estuarine benthic diatom species along salinity and nutrient gradients. Eur J Phycol 33:173-183

Wiltshire KH (1992) The influence of microphytobenthos on oxygen and nutrient fluxes between eulittoral sediments and associated water phases in the Elbe Estuary. In: Colombo G, Ferrari I., Ceccherilli VU, Rossi R (eds) Marine eutrophication and population dynamics. Proc 25th Eur Mar Biol Symp. Olsen and Olsen, Fredensborg, p 63-70

Submitted: January 4, 1999; Accepted: March 2, 1999

Proofs received from author(s): July 15, 1999 